Quebec Cooperative Study

of Friedreich's Ataxia

\title{
Glucose Tolerance and Erythrocyte Insulin Receptors in Friedreich's Ataxia
}

\author{
P. DRAPER. D. SHAPCOTT. A. LAROSE. J.STANKOVA, F. LEVESQUE AND B. LEMIEUX
}

SUMMARY: Detailed in vivo and in vitro studies of glucose and insulin metabolism in Friedreich's ataxia patients and unaffected family members have further defined the extent of the abnormalities in carbohydrate metabolism. The high incidence of glucose intolerance and a hyperinsulinemic response to a glucose challenge in a high percentage of Friedreich's ataxia patients has been confirmed. An increased incidence of glucose intolerance among heterozygotes is suggested, while the siblings show a more normal distribution of diabetes and a nearly normal insulin response to the glucose tolerance test.

RÉSUMÉ: Nous avons confirmé l'incidence élevée d'intolérance au glucose et de réponse hyperinsulinique à une surcharge glucosée chez un pourcentage élevé de patients avec l'ataxie de Friedreich. Une incidence augmentée est également suggérée chez les hétérozygotes alors que les taux de diabète sont plus près de la normale dans la fratrie, chez qui la réponse insulinique est à peu près normale. Les valeurs d'hormone de croissance humaine
Human growth hormone patterns are normal for all groups.

Preliminary studies of insulin binding to erythrocytes suggest a difference in the binding characteristics among diabetic Friedreich's ataxia patients, while the binding in the non-diabetic Friedreich's ataxia group is similar to that of nondiabetic controls. Results from a small group of non-diabetic siblings suggest $a$ normal insulin binding, while a tendency toward increased binding at low insulin concentrations among diabetic family members is noted.

sont normales dans tous les groupes.

Des études préliminaires concernant la liaison de l'insuline au niveau des érythrocytes indique qu'il semble exister une différence dans les caractéristiques de liaison chez les patients ataxiques diabétiques. La liaison de l'insuline est semblable à celle des sujets contrôles non diabétiques chez les Friedreich nondiabétiques.

\section{INTRODUCTION}

Previous studies in this and other laboratories have shown an elevated incidence of clinical and chemical diabetes in Friedreich's ataxia patients. Shapcott et al, (1976) found an incidence of $18.2 \%$ clinical diabetes and $21.2 \%$ chemical diabetes for a total of $39.4 \%$ in a group of 33 typical Friedreich's ataxia patients (Group Ia). In addition, an abnormally high insulin response to the glucose challenge was noted in $73 \%$ of the patients, and it was postulated that this could be the result of a deficiency of membrane receptors for insulin as has been reported for diabetic humans and animals.

Results of earlier studies on diabetes in Friedreich's ataxia have been summarized by Shapcott et al (1976).

The incidence of diabetes in relatives of Friedreich's ataxia patients has been studied less extensively. However, the results of a survey conducted by Andermann et al (1976) suggested an increased frequency among family members.

The possibility of a generalized membrane defect in Friedreich's ataxia has also been suggested. This was based in part on the preliminary observation of a difference in the stability of erythrocyte membranes in Friedreich's ataxia patients, as determined by SDS polyacrylamide electrophoresis (Shapcott et al, 1979).

In light of these findings, we have undertaken a study of the erythrocyte insulin receptors in Friedreich's ataxia patients and in unaffected family members. The survey of glucose and insulin metabolism of Shapcott et al (1976) has also been extended to include the family members in order to further delineate the extent of 
abnormalities in carbohydrate metabolism in obligatory heterozygotes and siblings.

\section{SUBJECTS AND METHODS}

\section{Subjects}

Typical Friedreich's ataxia (Group Ia) patients and non-affected family members (obligatory heterozygotes and siblings*) were studied. Control subjects were apparently healthy adult volunteers from laboratory and secretarial personnel.

\section{Materials and Methods:}

Glucose tolerance test (G.T.T.). The subjects were given a high carbohydrate diet for three days before the'test. They were tested on an outpatient basis and they were maintained in a resting position (sitting) for 30 minutes before the test, as well as during the test period. An oral glucose load of $100 \mathrm{~g}(1.75 \mathrm{~g} / \mathrm{kg}$ for smaller subjects) was given and blood samples were collected at $0,30,60,90,120$ and 180 minutes. Plasma glucose was determined by the solid phase radioimmunoassay. Glucose tolerance curves were evaluated according to the method of Danowski et al (1973).

\section{Insulin binding studies - erythrocytes}

Insulin binding to viable erythrocytes was determined (with fasțing blood samples) using the method of Gambhir et al (1977) with the following modifications: the erythrocyte preparations were obtained by washing red cells three times with saline and aspirating the top portion of the cell pellet with the saline after each wash. Suspensions of one volume red cells and one volume $\mathrm{pH} 7.8$ trisHEPES buffer were incubated in the presence of $0.1 \mathrm{ng} / \mathrm{ml}$ 125I labelled insulin and varying concentrations of unlabelled insulin (total incubation volume was $550 \mathrm{ul}$ ) as described by Gambhir (1977).

The cell pellet containing bound insulin was separated from free insulin by layering duplicate $200 \mu$ l samples of suspension on $0.5 \mathrm{ml}$ dibutylphthalate and $0.5 \mathrm{ml}$ buffer at $4^{\circ}$ in $12 \times 75 \mathrm{~mm}$ plastic tubes. After aspiration of the upper layer, the walls of the tubes were rinsed with $0.4 \mathrm{ml}$ buffer to ensure maximum removal of free insulin.

Specific binding of ${ }^{125} \mathrm{I}$ labelled insulin to erythrocytes was calculated by subtracting the binding of $125 \mathrm{I}$ insulin in the presence of $10^{5} \mathrm{ng} / \mathrm{ml}$ unlabelled insulin (non-specific binding) from the total binding. Hemoglobin was determined in the cell suspensions for each subject and the specific binding normalized to a hemoglobin concentration of $15.7 \mathrm{~g} /$ $100 \mathrm{ml}$ in the suspensions.

Insulin binding to lyophilized ghosts were measured by incubations of about 2-2.5 mg ghosts in the trisHEPES buffer for $4 \mathrm{~h}$ at $4^{\circ} \mathrm{C}$. Following the incubations, suspensions were centrifuged in $\mu$ centrifuge tubes and the ghost pellets washed with buffer to remove unbound insulin.

\section{RESULTS}

Distribution of the Danowski scores for the G.T.T. among the various groups (a total of 44 subjects) is shown in Table I. The increased incidence of glucose intolerance in the Friedreich's ataxia group is consistent with the results of previous studies. Similarly, a tendency toward increased glucose intolerance is observed for the obligatory heterozygotes, while the results for the siblings resemble those of the external controls.

Table II shows the insulin and H.G.H. responses to the glucose load in the different groups. These are presented graphically in Fig. la - d, with each group of subjects (where numbers are sufficient) being divided into "diabetic" and "non-diabetic" sub-groups. Here, a Danowski score of 600 was chosen arbitrarily as the dividing point between the two subgroups. It can be seen (Fig. la) that the diabetic Friedreich's ataxia patients studied exhibit a delayed hypoinsulinemic response to the glucose challenge, while the non-diabetic Friedreich's ataxia patients show a delayed and eventually a hyperinsulinemic response, relative to control subjects. The curve for the nondiabetic siblings (Fig. 1b) resembles that of the non-diabetic external controls. An increased insulin response appears to result from the glucose load in the obligatory heterozygote group. However, the number of subjects $(\mathrm{N}=6)$ available precludes a more precise classification of this group. No significant differences in the H.G.H. results among the groups are apparent (Table II, Fig. 1, c-d).

The specific binding of labelled insulin to erythrocytes as a function of
TABLE I

Distribution of Danowski Scores for Glucose Intolerance Sum of Plasma Glucose Levels at 0,30,60 and $120 \mathrm{~min}$

\begin{tabular}{lcccc}
\hline & $\begin{array}{c}501-650 \text { (chemical } \\
\text { diabetes, mild } \\
\text { glucose intolerance) }\end{array}$ & $\begin{array}{c}650-800 \text { (chemical } \\
\text { diabetes, moderate } \\
\text { glucose intolerance) }\end{array}$ & $\begin{array}{c}>800 \\
\text { (diabetes) }\end{array}$ & $\begin{array}{c}\text { Mean } \\
\text { Danowski }\end{array}$ \\
Scores ( \pm S.D.)
\end{tabular}

Friedreich's

Ataxia *

$(\mathrm{N}=15)$

1

11

3

$582.7 \pm 77.0$

Obligatory

Heterozygotes

$\mathrm{N}=6$ )

1

4

1

$639.9 \pm 201.0$

Siblings

$(\mathrm{N}=11)$

6

4

1

$513.1 \pm 92.7$

External

Controls

$(\mathrm{N}=12)$

5

6

1

$517.6 \pm 105.6$

* Excluded from this group was at least one known diabetic where the glucose tolerance test was not administered. 

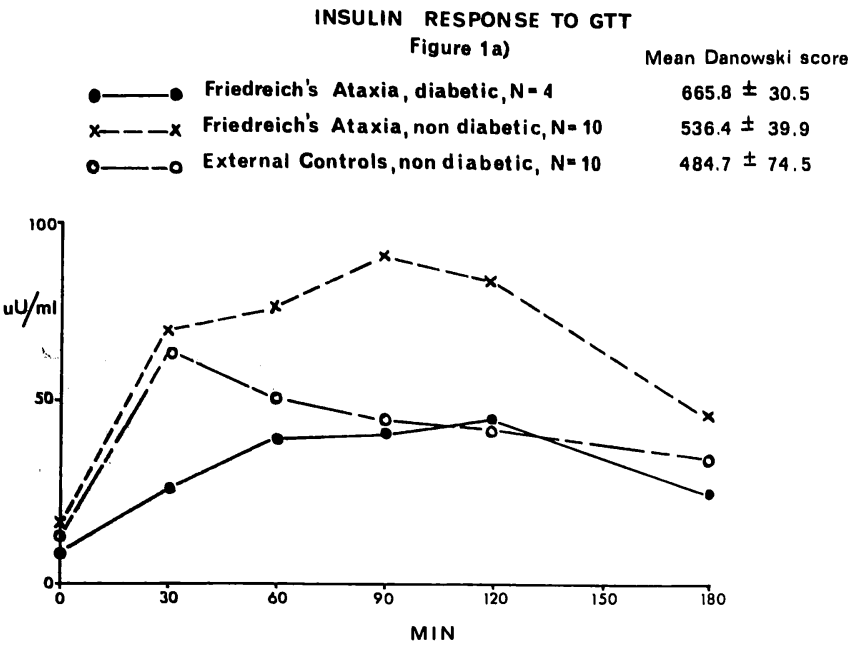

INSULIN RESPONSE TO GTT

Figure 1 b)

Mean Danowski score

$478.4 \pm 54.4$

$484.7 \pm 74.5$

$639.9 \pm 201.0$

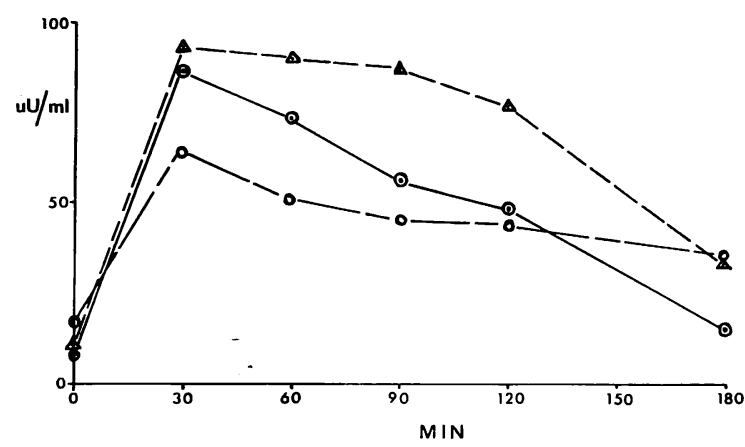

Figure 1, $a-b$-Insulin response to GTT. a) Friedreich's ataxia, diabetic and non diabetic. b) Siblings, non diabetic. Heterozygotes (diabetic + non diabetic).

the concentration of unlabelled insulin is summarized in Table III and is shown graphically in Fig. 2 a, b. Scatchard analyses of the binding are illustrated in Fig. 3 a, b.

The specific binding of insulin to erythrocytes of diabetic Friedreich's ataxia patients is significantly higher than that for non-diabetic controls at low concentrations of unlabelled insulin. The Scatchard plot also suggests a difference in the binding characteristics at high insulin concentrations in the diabetic Friedreich's ataxia group. However, because of the limited amounts of erythrocytes available, these results
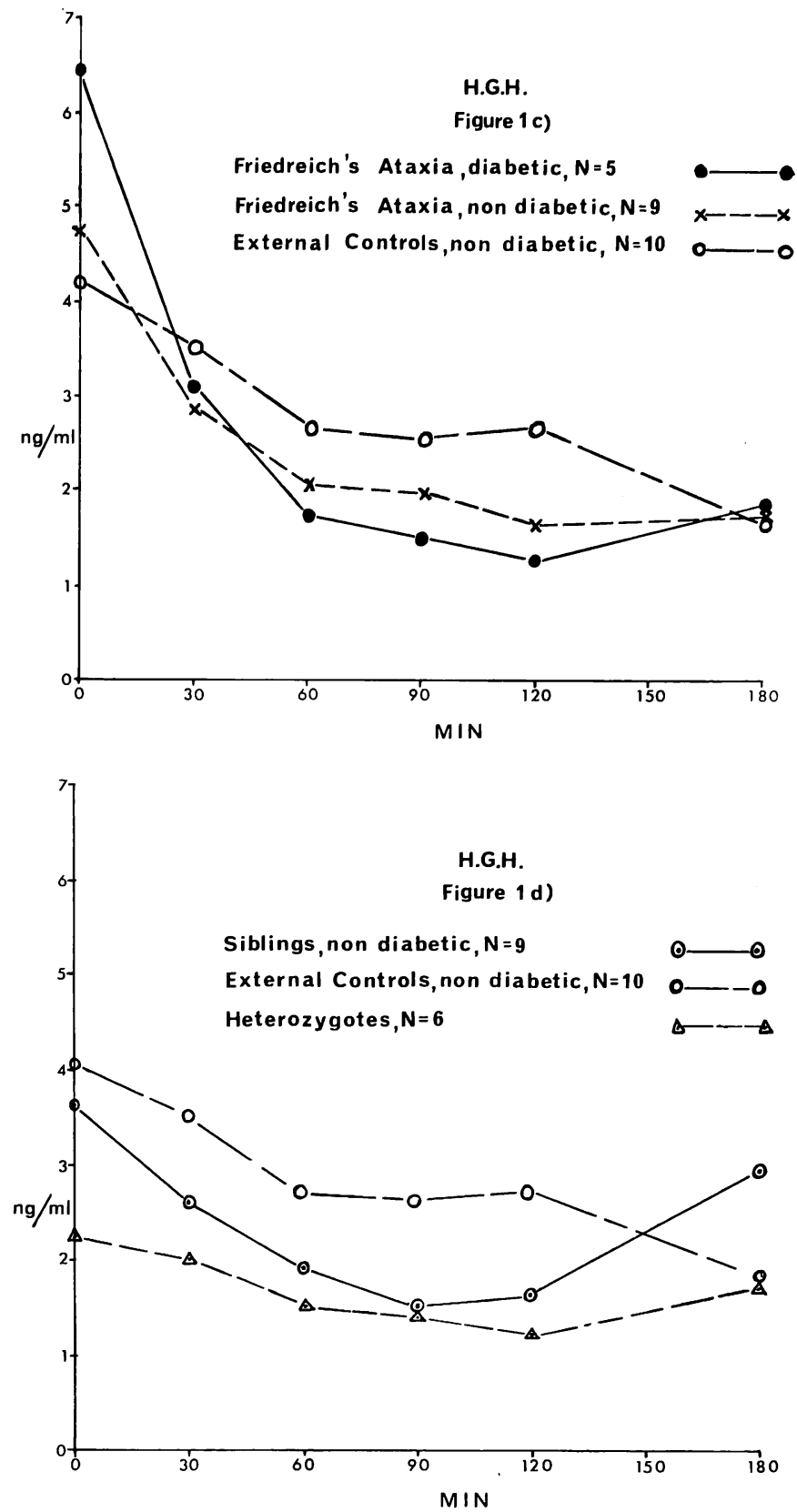

Figure 1, $c$-d-HGH response to GTT. c) Friedreich's ataxia, diabetic and non diabetic. d) Siblings, non diabetic. Heterozygotes (diabetic + non diabetic).

are based on the binding at just two insulin concentrations and a small uncertainty in the two points may result in a large uncertainty in the intercept. The specific binding for the non-diabetic Friedreich's ataxia group is not significantly higher than the non-diabetic control group. The binding curve for non-diabetic siblings is very similar to that for non-diabetic controls while a trend toward elevated binding at low unlabelled insulin concentrations is noted for diabetic heterozygotes and siblings. Due to the small number of subjects available, it was not considered practical to separate the diabetic heterozygotes and siblings into two groups. 


\section{DISCUSSION}

The increased incidence of glucose intolerance in genetic disorders such as inherited ataxias and some neuromuscular disorders has been extensively documented (Shapcott et al, 1976, Barbosa et al, 1974). However, the relationship between the glucose intolerance and the primary biochemical defect remains obscure. An hypothesis which we are currently investigating is that the clinical signs in these disorders are the result of a defect in cell membranes. Since insulin receptors are located on the surface of cell membranes, it is conceivable that the membrane defect could affect insulin binding characteristics and hence carbohydrate metabolism. From an alternative point of view, a study of insulin receptors could be used as a probe for the further elucidation of membrane function and possible defects.

The increased incidence of glucose intolerance in Friedreich's ataxia, is shown in Table I. The majority of the patients exhibit a mild degree of glucose intolerance. Thoren (1978), in a follow-up study of a group of Friedreich's ataxia patients first reported in 1964, noted an increase
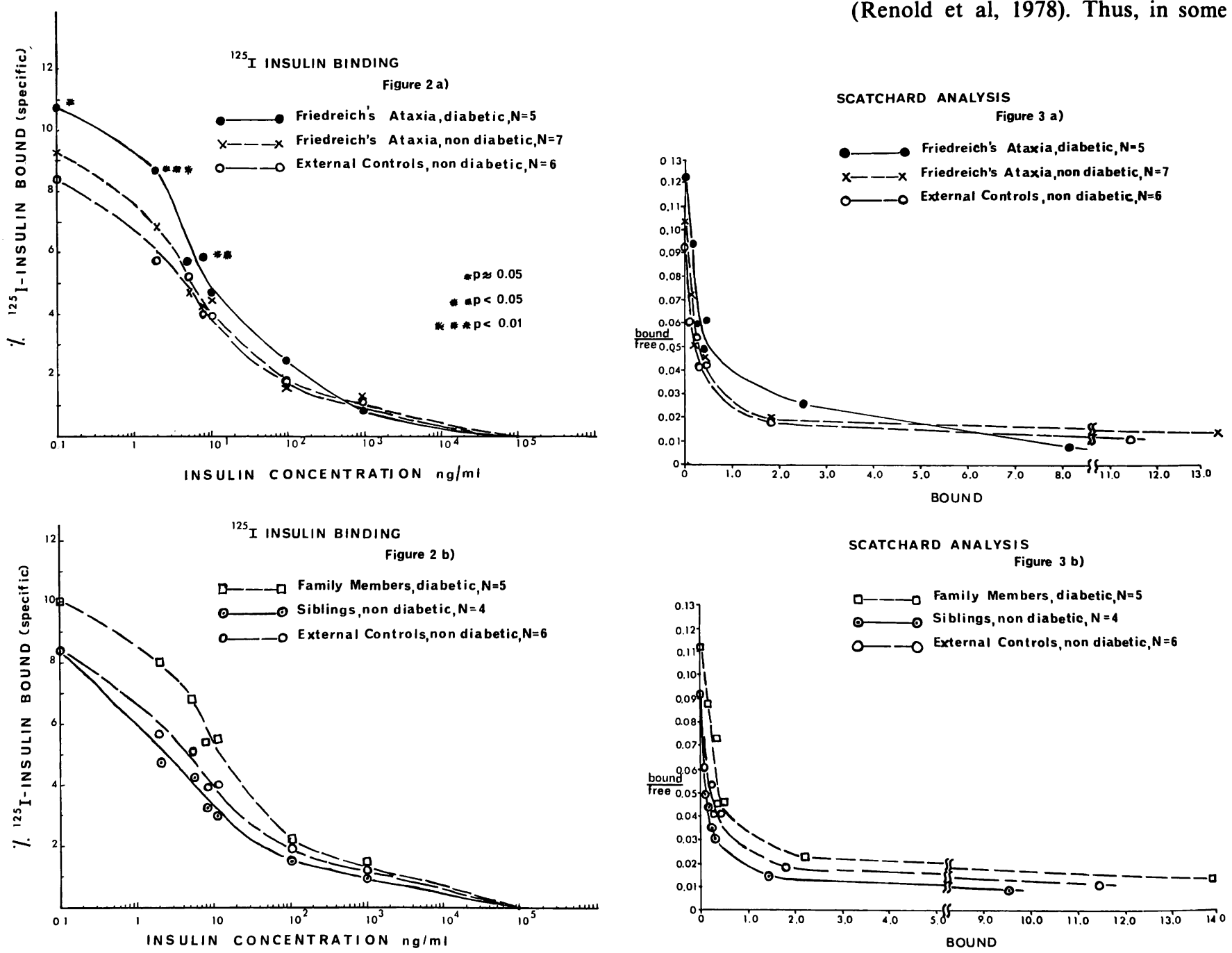

Figure 2, $a-b-{ }^{125}$ I insulin binding to erythrocytes. a) Friedreich's ataxia, diabetic and non diabetic. b) Family members, diabetic. Siblings, non diabetic.

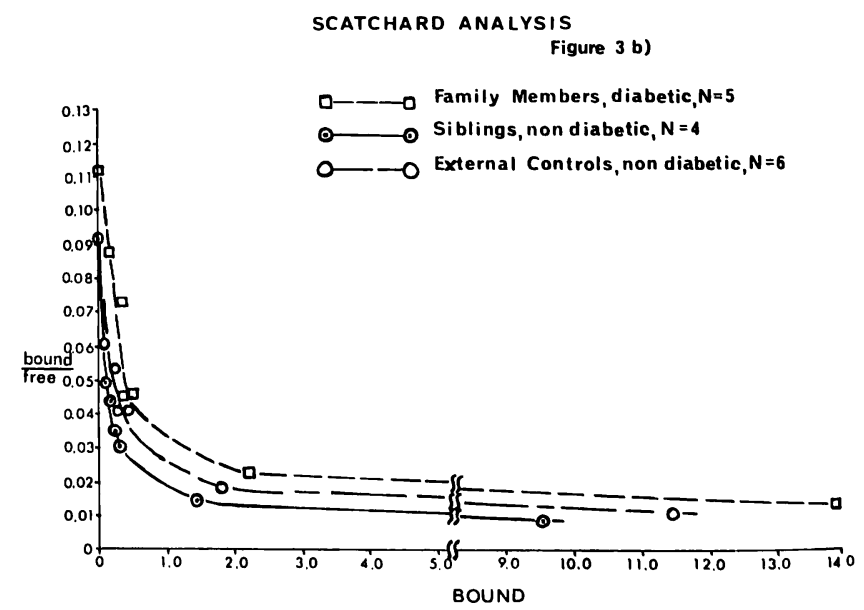

Figure 3, $a-b-$ Scatchard analysis of 125 I Insulin binding to erythrocytes. a) Friedreich's ataxia, diabetic and non diabetic. b) Family members, diabetic. Siblings, non diabetic. 
TABLE II

Insulin and HGH Responses to GTT(Mean \pm S.D.)

\begin{tabular}{|c|c|c|c|c|c|c|c|}
\hline & & $0 \mathrm{~min}$ & $30 \mathrm{~min}$ & $60 \mathrm{~min}$ & $90 \mathrm{~min}$ & $120 \mathrm{~min}$ & $180 \mathrm{~min}$ \\
\hline $\begin{array}{l}\text { Friedreich's } \\
\text { Ataxia } \\
\text { (Diabetic) }\end{array}$ & $\begin{array}{l}\mathrm{HGH} \\
(\mathrm{ng} / \mathrm{ml} \mathrm{N}=5) \\
\text { INS } \\
(\mathrm{uU} / \mathrm{ml} \mathrm{N}=4)\end{array}$ & $\begin{array}{c}6.38 \pm 7.70 \\
8.4 \pm 5.7\end{array}$ & $\begin{array}{l}3.12 \pm 2.16 \\
25.5 \pm 17.5\end{array}$ & $\begin{array}{l}1.84 \pm 0.69 \\
39.8 \pm 22.3\end{array}$ & $\begin{array}{l}1.60 \pm 0.35 \\
40.8 \pm 23.8\end{array}$ & $\begin{array}{l}1.34 \pm 0.32 \\
44.8 \pm 28.1\end{array}$ & $\begin{array}{l}1.86 \pm 1.14 \\
23.8 \pm 17.6\end{array}$ \\
\hline $\begin{array}{l}\text { Friedreich's } \\
\text { Ataxia } \\
\text { (Non-Diabetic) }\end{array}$ & $\begin{array}{l}\text { HGH } \\
(N=9) \\
\text { INS } \\
(N=10)\end{array}$ & $\begin{array}{l}4.66 \pm 4.74 \\
15.7 \pm 18.1\end{array}$ & $\begin{array}{l}2.92 \pm 1.61 \\
69.6 \pm 38.5\end{array}$ & $\begin{array}{l}2.13 \pm 1.39 \\
77.4 \pm 55.0\end{array}$ & $\begin{array}{l}2.01 \pm 1.20 \\
91.0 \pm 51.9\end{array}$ & $\begin{array}{l}1.73 \pm 1.51 \\
84.1 \pm 52.6\end{array}$ & $\begin{array}{l}1.83 \pm 0.96 \\
46.2 \pm 38.2\end{array}$ \\
\hline $\begin{array}{l}\text { Siblings } \\
\text { (Non-Diabetic) }\end{array}$ & $\begin{array}{l}\text { HGH } \\
(N=9) \\
(N=9)\end{array}$ & $\begin{array}{c}3.63 \pm 2.90 \\
7.8 \pm 3.3\end{array}$ & $\begin{array}{l}2.59 \pm 2.36 \\
86.0 \pm 52.7\end{array}$ & $\begin{array}{r}1.89 \pm 1.63 \\
73.0 \pm 53.9\end{array}$ & $\begin{array}{l}1.47 \pm 0.85 \\
55.8 \pm 32.8\end{array}$ & $\begin{array}{l}1.64 \pm 0.78 \\
47.2 \pm 20.2\end{array}$ & $\begin{array}{l}2.88 \pm 1.29 \\
13.4 \pm 9.5\end{array}$ \\
\hline $\begin{array}{l}\text { External } \\
\text { Controls } \\
\text { (Non-Diabetic) }\end{array}$ & $\begin{array}{l}\text { HGH } \\
(N=10) \\
\text { INS } \\
(N=10)\end{array}$ & $\begin{array}{l}4.10 \pm 4.27 \\
13.3 \pm 17.0\end{array}$ & $\begin{array}{l}3.52 \pm 4.15 \\
63.9 \pm 31.7\end{array}$ & $\begin{array}{l}2.69 \pm 2.36 \\
51.0 \pm 27.6\end{array}$ & $\begin{array}{l}2.66 \pm 3.00 \\
42.5 \pm 33.2\end{array}$ & $\begin{array}{l}2.74 \pm 2.19 \\
44.4 \pm 30.8\end{array}$ & $\begin{array}{l}1.76 \pm 1.36 \\
33.4 \pm 21.0\end{array}$ \\
\hline $\begin{array}{l}\text { Heterozygotes } \\
\text { (diabetic }+ \\
\text { non-diabetic) }\end{array}$ & $\begin{array}{l}\text { HGH } \\
(N=6) \\
\text { INS } \\
(N=10)\end{array}$ & $\begin{array}{r}2.28 \pm 1.02 \\
10.16 \pm 3.75\end{array}$ & $\begin{array}{c}2.05 \pm 0.96 \\
92.92 \pm 87.97\end{array}$ & $\begin{array}{l}1.52 \pm 0.67 \\
90.0 \pm 55.32\end{array}$ & $\begin{array}{c}1.45 \pm 0.61 \\
87.33 \pm 36.11\end{array}$ & $\begin{array}{c}1.22 \pm 0.46 \\
76.33 \pm 37.38\end{array}$ & $\begin{array}{c}1.72 \pm 0.70 \\
32.92 \pm 28.00\end{array}$ \\
\hline
\end{tabular}

families glucose intolerance appears in heterozygotes and in siblings as well, as in the Friedreich's ataxia patients, while other families appear to be relatively free of diabetic complications.

An additional factor is that Friedreich's ataxia patients are poor subjects for a GTT since their low muscle mass would cause them to utilize glucose abnormally, irrespective of their glucose intolerance. While there are a number of obviously diabetic Friedreich's ataxia patients in our group, it is possible that this abnormal glucose utilization may be an important factor in the large number of borderline cases. We are currently investigating the concentration of the minor hemoglobin $A_{1 C}$ which gives an indication of the extent of hyperglycemia over the preceding several weeks without resorting to the GTT (Renold et al, 1978; Gonen et al, 1978).

For the purpose of this discussion of insulin metabolism, the subjects have been divided into "diabetic" and "nondiabetic" sub-groups, with a Danowski score of 600 being arbitrarily chosen as the dividing point between the two. Thus, subjects having a Danowski score of less than 600 will

TABLE III

$\%{ }^{125 I}$ Insulin Bound (Specific), \pm S. D. $/ 15.7 \mathrm{~g} \% \mathrm{Hb}$

\begin{tabular}{cccrrr}
\hline $\begin{array}{c}\text { Concentration of } \\
\text { non-labelled } \\
\text { insulin (ng/ml) }\end{array}$ & $\begin{array}{c}\text { Friedreich's } \\
\text { Ataxia, Diabetic } \\
(\mathbf{N}=\mathbf{5})\end{array}$ & $\begin{array}{c}\text { Friedreich's } \\
\text { Ataxia, Non- } \\
\text { Diabetic (N=7) }\end{array}$ & $\begin{array}{c}\text { Family Members } \\
\text { Diabetic } \\
\mathbf{( N = 5 )}\end{array}$ & $\begin{array}{c}\text { Siblings } \\
\text { Non-Diabetic } \\
\mathbf{( N = 4 )}\end{array}$ & $\begin{array}{c}\text { External } \\
\text { Controls, Non } \\
\text { diabetic (N=6) }\end{array}$ \\
\hline 0 & $10.79 \pm 2.18^{*}$ & $9.31 \pm 1.64$ & $10.04 \pm 2.71$ & $8.38 \pm 2.81$ & $8.41 \pm 1.14$ \\
2 & $8.60 \pm 0.69 * * *$ & $6.75 \pm 1.05$ & $8.07 \pm 3.28$ & $4.66 \pm 1.66$ & $5.73 \pm 1.48$ \\
5 & $5.64 \pm 1.17$ & $4.78 \pm 1.11$ & $6.83 \pm 2.28$ & $4.23 \pm 1.16$ & $5.11 \pm 0.98$ \\
8 & $5.87 \pm 1.15 * *$ & $4.10 \pm 0.66$ & $4.39 \pm 1.57$ & $3.37 \pm 1.24$ & $3.99 \pm 0.91$ \\
10 & $4.60 \pm 0.46$ & $4.39 \pm 1.69$ & $4.49 \pm 1.60$ & $2.97 \pm 1.68$ & $3.96 \pm 1.25$ \\
$10^{2}$ & $2.49 \pm 0.80$ & $1.87 \pm 1.03$ & $2.21 \pm 1.77$ & $1.47 \pm 1.53$ & $1.84 \pm 0.59$ \\
$10^{3}$ & $0.81 \pm 0.44$ & $1.36 \pm 0.60$ & $1.38 \pm 1.20$ & $0.95 \pm 0.82$ & $1.14 \pm 0.57$ \\
$10^{5}$ & & & & & \\
\hline
\end{tabular}

$* p \approx 0.05$

$* * \mathrm{p}<0.05$

$* * * \mathrm{p}<0.01$

Diabetic $=$ Danowski Score $>600$

Non-Diabetic $=$ Danowski Score $<600$

have either a normal GTT or they will exhibit a mild degree of glucose intolerance. Subjects with a score of greater than 600 show a more severe degree of intolerance and hence are classified as "diabetic". A more extensive classification as shown in Table I was not considered practical due to the limited number of subjects.

The hyperinsulinemic response to the GTT among the non-diabetic Friedreich's ataxia patients parallels the slight hyperglycemic response of this group and thus a certain degree of insulin resistance is suggested. A similar type of hyperinsulenemia has been reported in patients with myotonic dystrophy (Barbosa et al, 1974). However, the degree of hyperinsulinemia found in our study is much less than that reported by Bar et al (1978) for two siblings with ataxia telangiectasia. In the diabetic Friedreich's ataxia patients where 
insulin concentration was measured, a delayed hypoinsulinemic response was observed (Fig. la).

The first step in the metabolism of insulin is considered to be the interaction of insulin with its target cell receptors. Since defective insulin binding has been associated with abnormalities of insulin metabolism, it was therefore of interest to attempt to make a correlation between the in vivo insulin responses and the data obtained from the insulin binding studies.

Most previous studies on circulating insulin receptors have been conducted on monocytes. However, the amount of blood required to isolate sufficient quantities for detailed studies is large and we felt that the procedure was too invasive. While less is known of the characteristics of erythrocyte insulin receptors, the development of a convenient procedure for the measurement of these receptors by Gambhir et al (1977) prompted us to use erythrocytes. In a more recent paper, Gambhir et al (1978) have shown that binding characteristics of erythrocytes are similar to other human cell types.

Lyophilized erythrocyte membranes (ghosts) represent a very stable and therefore convenient preparation, and since we were already preparing ghosts for other membrane studies, our initial work with erythrocyte receptors was done with the ghost preparation. We were able to demonstrate specific binding of radiolabelled insulin to the erythrocyte ghost-preparation and insulin binding at three different concentrations of non-labelled insulin was determined for Friedreich's ataxia patients, obligatory heterozygotes, siblings, and external controls. No differences among the groups were observed. However, our method resulted in a high percentage of non specific binding (about $60 \%$ of the total binding), and the quantity of insulin specifically bound was much less than measured with an equivalent quantity of fresh erythrocytes. Therefore, it appears that the insulin receptors are partially lost or modified during the preparation of the ghosts. We thought it unsound to draw conclusions from the results obtained with the ghosts.
The most important feature of the insulin binding curves (fig. 2a, b) is probably the increased binding of $125 \mathrm{I}$ insulin in the presence of low concentrations of unlabelled insulin to erythrocytes of diabetic Friedreich's ataxia patients. Bar and Roth (1977) have reviewed the correlations found between the concentration of a number of circulating hormones and the concentration and affinity of insulin receptors on circulating monocytes. Of particular importance is the concentration of insulin itself; studies of hyperinsulinemia in obesity and adult diabetes, as well as animal studies of hypoinsulinemia show an inverse relationship between plasma insulin levels and receptor concentrations. In view of the low fasting insulin concentrations in many of the diabetic Friedreich's ataxia patients, the higher binding at low insulin concentrations therefore appears reasonable. The apparently lower total receptor concentration for this group, as determined by the intercept of the Scatchard curve (Fig. 3a), seems surprising. However, the intercept of the curves is obtained by extrapolation of just two points in this case and thus they are subject to a considerable degree of uncertainty. Although the non-diabetic Friedreich's ataxia patients give a delayed hyperinsulinemic response to the GTT, the near normal fasting insulin levels are consistent with the near normal binding characteristics of this group.

A number of other factors including the presence of circulating inhibitors of insulin binding (antireceptor antibodies) (Bar et al, 1977), $\mathrm{HGH}$ concentrations (Sommen et al, 1978), and ingestion of glucose (Muggeo et al, 1977) have been shown to affect insulin binding. Our results show no significant differences in the $\mathrm{HGH}$ responses to the GTT in any of the groups studied. It seems unlikely that the binding differences are related to HGH abnormalities.

There are no data on insulin binding to erythrocytes of diabetic subjects. We are currently carrying out binding studies on diabetic controls not suffering from neurological disorders to confirm whether or not the difference in binding occurs independently of the ataxia. Of probable significance here is a similar trend toward an increase in ${ }^{125} \mathrm{I}$ insulin binding at low concentrations of unlabelled insulin to erythrocytes of diabetic heterozygotes and siblings, compared to non-diabetic controls and siblings.

Defects in insulin binding to monocytes, as are found in insulin resistance or in $\mathrm{HGH}$ deficiency are generally acquired defects, since the receptors usually return to normal when the precipitating factor is regulated (Bar et al, 1977). In a relevant example, a large decrease in insulin receptor affinity on monocytes of two siblings with ataxia telangiectasia and severe insulin resistance was reported by Bar et al (1978). However, the defect was not expressed in cultured fibroblasts, suggesting that it was not a basic genetic defect. In this example, evidence for the presence of circulating antireceptor antibodies was obtained.

In contrast, it has been suggested that defects in insulin receptors in thin, insulin resistant diabetics are of genetic origin (Blecher, 1979).

Studies of insulin binding to cultured fibroblasts of Friedreich's ataxia patients are therefore planned to confirm whether or not the difference observed in erythrocytes is expressed.

A number of other possibilities have been suggested to account for insulin resistance. These include secretion of an abnormal insulin or a defect at the second messenger level, but evidence of these is less conclusive. The failure to observe a significant difference in the binding to erythrocytes of nondiabetic Friedreich's ataxia patients where a hyperinsulinemic response to the GTT was observed leaves open the possibility of a defect at a later control stage. Alternatively, it is possible that defects in insulin receptors in the major target cells are not manifested in erythrocytes.

In conclusion, we have confirmed the increased incidence of diabetes in Friedreich's ataxia patients and the hyperinsulinemic response to the GTT in many cases. An increased incidence of glucose intolerance in the obligatory heterozygotes is suggested but the siblings show a more normal distribution of diabetes. Binding of ${ }^{125}$ I 
insulin to erythrocytes of non-diabetic Friedreich's ataxia patients and siblings does not differ significantly from normal while an increased binding is observed for diabetic Friedreich's ataxia patients. Since the binding appears normal in many cases, it seems unlikely that Friedreich's ataxia is related to a primary defect in insulin receptors; however, the insulin resistance may be secondary to a generalized membrane defect.

\section{ACKNOWLEDGMENTS}

The studies reported in this paper were supported in part by a grant from l'Association Canadienne de l'Ataxie de Friedreich. We also wish to acknowledge the technical assistance of Mrs. Gisèle Carrier and Miss Lucie Chouinard.

\section{REFERENCES}

ANDERMANN, E., RÉMILLARD, G. M., GOYER, G., BLITZER, L., and BARBEAU, A. (1976). Genetic and Family studies in Friedreich's Ataxia. Can. J. Neurol. Sci. 3, 287-301.

BAR, R. S., and ROTH, J. (1977). Insulin receptor Status in Disease States of Man. Arch. Int. Med., 137, 474-481.
BAR, R. S., LEVIS, W. R., RECHLER, M. M., HARRISON, L. C., SIEBERT, C., PODSKALNY, J., ROTH, J., and MUGGEO, M. (1978). Extreme insulin resistance in Ataxia Teangiectasia. Defect in affinity of insulin receptors. New England J. Med., 298, 1164-1171.

BARBOSA. J., NUTTALL, F. Q., KENNEDY, W., and GOETZ, F. (1974). Plasma Insulin in Patients with Myotonic Dystrophy and their Relatives. Medicine, Vol. 53, 307-323.

BLECHER, M. (1979). Cell-surface receptors in health and disease. Clin. Chem. 25, 11-19.

DANOWSKI, T. S., KHURANA, R. C., NOLAN, S., STEPHAN, T., GEGICK, C. G., CHAE, S., and VIDALON, C. (1973). Insulin patterns in equivocal glucose tolerance tests (chemical diabetes). Diabetes, 22, 808-812.

GAMBHIR, K. K., ARCHER, J. A., and CARTER, L. (1977). Insulin radioreceptor for human erythrocytes. Clin. Chem., 23, 1590-1595.

GAMBHIR, K. K., ARCHER, J. A., and BRADLEY, C. J. (1978). Characteristics of Human Erythrocyte Insulin Receptors. Diabetes, 27, 701-708.

GONEN, B., and RUBENSTEIN, A. H. (1978). Haemoglobin $A 1$ and diabetes mellitus. Diabetologia, 15, 1-8.
MUGGEO, M., BAR, R. S., and ROTH, J. (1977). Change in affinity of insulin receptors following oral glucose in normal adults. J. Clin. Endocrinol. Metab., 44, 1206-1209.

RENOLD, A. E., MINTZ, D. H., MULLER, W. A., and CAHILL, G. F., Jr. (1978). Diabetes Mellitus. In: The Metabolic Basis of Inherited Disease, 4th edition. (Stanbury, J. B., Wyngaarden, J. B., and Fredrickson, D. S., eds) McGraw-Hill, New York, p80109.

SHAPCOTT, D., MELANCON, S., BUTTERWORTH, R. F., KHOURY, K., COLLU, R., BRETON, G., GEOFFROY, G., LEMIEUX, B., and BARBEAU, A. (1976). Glucose and Insulin metabolism in Friedreich's ataxia. Can. J. Neurol. Sci. 3, 361-364.

SOMMEN, V., TAMBORLANE, W., DE FRONZO, R., GENEL, M., and FELIG, P., (1978). Insulin binding and insulin sensitivity in Isolated Growth Hormone Deficiency. New Engl. J. Med. 299, 1025-1030.

THOREN, C. (1978). Note on diabetes mellitus in a prospective study of Friedreich's ataxia. In: Advances in Neurology, vol. 21. The inherited ataxias: biochemical, viral and pathological studies. (Kark, R.A.P., Rosenberg, R.N., and Schut, L. J. eds). Raven Press, New York, pp 391-393. 